References
1 Morrisey RT, Shore SL. Bone and joint sepsis. Pediatr Clin
North Am 1986;33:1551-64.
2 Anonymous. Bacterial arthritis. Lancet 1986;ii:721-2.
${ }^{3}$ Golden SE, Kelly JC. Pneumococcal meningitis complicated by
immune complex-mediated arthritis. Am J Dis Child 1987;141:
603-4.
${ }^{4}$ Rush PJ, Shore A, Inman R, et al. Arthritis associated with
Haemophilus influenzae meningitis: septic or reactive? J Pediat 1986;109:412-5.

Correspondence to Dr A Earley, Department of Paediatrics, Northwick Park Hospital, Watford Road, Harrow, Middlesex HA1 3UJ.

Accepted 18 April 1988

\title{
Growth hormone, suspected gonadotrophin deficiency, and ring 18 chromosome
}

\author{
S S ABUSREWIL, ${ }^{*}$ A McDERMOTT, $\dagger$ AND D C L SAVAGE* \\ ${ }^{*}$ Bristol Children's Hospital and †South Western Regional Cytogenetics Service, Southmead Hospital, Bristol
}

SUMMARY A boy with a ring 18 chromosome karyotype was referred because of short stature; he had growth hormone deficiency and possible hypogonadotrophic hypogonadism. Many children with major chromosomal abnormalities are short, but this case emphasises the need to consider growth hormone deficiency in addition.

About 60 patients with a ring 18 chromosome karyotype have been reported. ${ }^{1}$ Phenotypically they are short and obese with mild dysmorphic features including hypertelorism, epicanthic folds, slight micrognathia, and small hands with short, tapering fingers. Boys may have a small penis and cryptorchism. All have pronounced retardation of growth and there have been two reports of additional growth hormone deficiency. ${ }^{23}$ We report a child with growth hormone deficiency and possible gonadotrophin deficiency.

\section{Case report}

The boy was born to healthy non-consanguinous parents at 40 weeks' gestation weighing $4900 \mathrm{~g}$. $\mathrm{He}$ had a low Apgar score and resuscitation included a brief period of intubation. His development was delayed and at 3.5 years he was noted to be short (height $-3 \mathrm{SD}$ ) and comparatively obese (weight 10 th centile), with an unusual facies. Examination of the peripheral lymphocytes showed an abnormal male karyotype of 46 chromosomes, including one ring 18 chromosome. The precise breakpoints in the formation of the ring chromosome could not be determined, but the morphology and stability of the ring implied that the deleted distal segments were comparatively small. The parents' chromosomes were normal.
At the age of 12 he was referred to the growth clinic because of pronounced retardation of growth and obesity. His height was $112 \mathrm{~cm}(-4.8 \mathrm{SD})$, and he weighed $37 \mathrm{~kg}$ (50th centile). He had several of the dysmorphic features that are described in children with ring 18 karyotype including a small penis $(<2 \mathrm{~cm}$ long) with small soft testicles $(<2 \mathrm{ml}$ volume) (figure). His sense of smell was normal, and his skeletal age was $9 \cdot 1$ years. Serum thyroxine, thyroid stimulating hormone, prolactin, and cortisol concentrations were all normal. A sequential insulin and arginine stimulation test after priming with $100 \mu \mathrm{g}$ ethinyloestradiol daily for three days confirmed growth hormone deficiency with unrecordable growth hormone concentrations despite adequate hypoglycaemia $(4.2 \mathrm{mmol} / \mathrm{l} \rightarrow 2 \mathrm{mmol} / \mathrm{l})$. The pituitary sella was small but a brain scan was normal. He was given growth hormone (Somatonorm) 4 units subcutaneously three times a week, and his height velocity (which had been $4.8 \mathrm{~cm} /$ year before treatment) increased to $10.8 \mathrm{~cm} /$ year during the first full year of treatment.

At the age of 14.3 years he was still prepubertal His gonadotrophin response to gonadotrophin releasing hormone was poor with a peak measurement of luteinising hormone of $3.1 \mathrm{IU} / \mathrm{l}$ and a peak measurement of follicle stimulating hormone of $2 \cdot 1$ IU/l. Basal testosterone concentration was $0 \cdot 1$ $\mathrm{nmol} / \mathrm{l}$. The addition of testosterone enanthate 100 $\mathrm{mg}$ intramuscularly monthly has accelerated his growth (which at the time of writing was 9.7 $\mathrm{cm} /$ year), and induced sexual maturation.

\section{Discussion}

A ring 18 chromosome karyotype is comparatively rare; there is loss of small distal segments of both long and short arms of the chromosome so that a mixture of physical signs characteristic of $18 \mathrm{p}-$ and 
$18 q-$ can be expected ${ }^{4}$ Transmission of the disorder from parent to child has been reported ${ }^{5}$ but most cases are mutations.

We know of two reports of children with chromosome 18 deletions and growth hormone deficiency, ${ }^{2}{ }^{3}$ but most authors do not measure growth hormone concentrations. There are reports of primary hypoparathyroidism and primary hypothyroidism, but none of gonadotrophin deficiency though some boys have small penises and testicles.

A causal association between growth hormone deficiency and 18 chromosome deletion is difficult to justify, as the gene for growth hormone production seems to lie on chromosome 17. Our patient was resuscitated in the neonatal period and perinatal asphyxia causing hypothalamic damage cannot be ruled out as the cause. His brain scan was normal so that there was no gross anatomical cerebral abnormality, but the pituitary sella was abnormally small.

Three reports of growth hormone deficiency in a comparatively rare chromosome disorder suggest that hypopituitarism should be sought for in children with this chromosome deletion and short stature. Some children seen in growth clinics are dysmorphic, or have minor or major chromosome abnor- malities, and usually paediatricians regard these children's short stature as part of their particular disorder. This case emphasises the need to measure growth hormone concentrations if height velocity is decreasing or retardation of growth is severe.

\section{References \\ ${ }^{1}$ Schinzel A. Autosomal chromosomal. Archiv Für Genetik (Zurich) 1979;52:1-204. \\ 2 Leisti J, Leisti S, Perheentupa J, Savilahti E, Aula P. Absence of IgA and growth hormone deficiency associated with short arm deletion of chromosome 18. Arch Dis Child 1973;48:320-2. \\ ${ }^{3}$ Buffoni L, Tarateta A, Aicandi G, et al. Nanismo ipofisario e sindrome malformativa multipla "tipo Goldenhar" in soggetto con delezione del braccio del cromosoma 18. Minerva Pediatr 1976;28:716-29. \\ ${ }^{4}$ Grouchy J De. The $18 p-, 18 q-$ and $18+$ syndromes in birth defects. Original Article Series, Vol V. The clinical delineation of birth defects. Part V. Phenotypic aspects of chromosomal abbreviations. National Foundation-March of Dimes, Baltimore: Williams and Wilkins, 1969:74-87. \\ 5 Chustensen KR, Friedrich U, Jacobsen P, et al. Ring chromo- some 18 in mother and daughter. J Ment Defic Res 1970;14: 49-67.}

Correspondence to Dr DCL Savage, Bristol Royal Hospital for Sick Children, St Michael's Hill, Bristol BS2 8BJ.

Accepted 21 January 1988

\title{
Glaucoma as an early complication of Hurler's disease
}

\author{
M J NOWACZYK, J T R CLARKE, ${ }^{*}$ AND J D MORIN $\dagger$ \\ Departments of Paediatrics, *Genetics, and †Ophthalmology, Hospital for Sick Children and University of \\ Toronto, Toronto, Canada
}

\begin{abstract}
SUMMARY We report three cases of Hurler's disease in which glaucoma developed in early childhood. We draw attention to the fact that glaucoma may be a commonly unrecognised early complication of this condition.
\end{abstract}

Glaucoma has been reported as a complication of mucopolysaccharide (MPS) storage diseases in adults with milder variants, such as Scheie disease (MPS IS). ${ }^{1}$ A single case of glaucoma in a child with Hurler's disease (MPS IH) was reported by Spellacy et $a .^{2}$ The authors speculated that glaucoma only develops late in milder forms of MPS storage diseases, and is rarely seen in patients with MPS IH because of their short life expectancy.

\section{Case reports}

CASE 1

A girl, weighing $3886 \mathrm{~g}$, was born at term to nonconsanguinous black parents. Noisy breathing and snoring were reported from early infancy. There was initially mild, but subsequently more severe and progressive, developmental delay. Congenital glaucoma was suspected at 16 months of age because of corneal clouding. At 18 months of age, she had many characteristic clinical features of MPS storage, including large head $(49.0 \mathrm{~cm},>98$ th percentile), depressed nasal bridge, thick lips, large tongue, dysplastic teeth, hepatosplenomegaly, and a mild gibbus and flaring of the lower ribcage. Radiographic examination of the skeleton showed changes typical of Hurler's disease (MPS IH). The diagnosis was confirmed by the demonstration of absence of $\alpha$ iduronidase in leucocytes and cultured skin fibroblasts.

Pronounced corneal opacities were noted on examination. Examination under anaesthesia showed corneal diameters of $12.25 \mathrm{~mm}$ in the left eye and $12.50 \mathrm{~mm}$ in the right eye. Pressure was $3.07 \mathrm{kPa}$ in the right eye, and $3.20 \mathrm{kPa}$ in the left. There was 